\title{
Three-dimensional EBSD Analysis and TEM Observation for Interface Microstructure during Reverse Phase Transformation in Low Carbon Steels
}

\author{
Kengo HatA $^{1)^{*}}$, Kazuki FujiwarA ${ }^{1)}$, Kaori $\mathrm{KaWAnO}^{1)}$, Masaaki SugIYAmA ${ }^{2)}$, Takashi FukudA $^{2)}$ and \\ Tomoyuki KaKESHITA ${ }^{2,3)}$ \\ 1) Advanced Technology Research Laboratories, Nippon Steel Corporation \\ 2) Department of Materials Science and Engineering, Osaka University \\ 3) Fukui University of Technology
}

Abstract: For the development of advanced steels, phase transformation from ferrite $(\alpha)$ to austenite $(\gamma)$ is essentially important to control the austenite phase in the heating process. Formation of austenite during the initial stage of $\alpha \rightarrow \gamma$ transformation from the recrystallized ferrite in low carbon steel has been studied from the view-point of the orientation relationships and the interphase boundary structure. At high temperature, the in situ electron backscattering diffraction (EBSD) analysis of austenite grain growth during the $\alpha \rightarrow \gamma$ transformation indicates that the different migration behaviors according to different $\alpha / \gamma$ interfaces, derive from the interfacial coherency with the specific orientation relationships. The orientation and microstructure of the interface between ferrite and austenite have been investigated using the 3D crystal orientation analysis and transmission electron microscopy (TEM) observations. When the crystal orientation relationship between ferrite and austenite grain are close to the Kurdjumov-Sachs relationship, the grain boundary normal itself is also close to the $\{111\}_{\alpha}$ and $\{011\}_{\gamma}$, respectively. The microstructure of these interfacial planes is revealed to be flat using 3D-EBSD and TEM analysis. These coherent planes are strongly connected to the formation of the austenite phase on heating and also affect the slow migration of the grain-growth process.

Keywords: phase transformation; crystal orientation relationship; Interface boundary plane; three-dimensional EBSD analysis; TEM observation; low carbon steel.
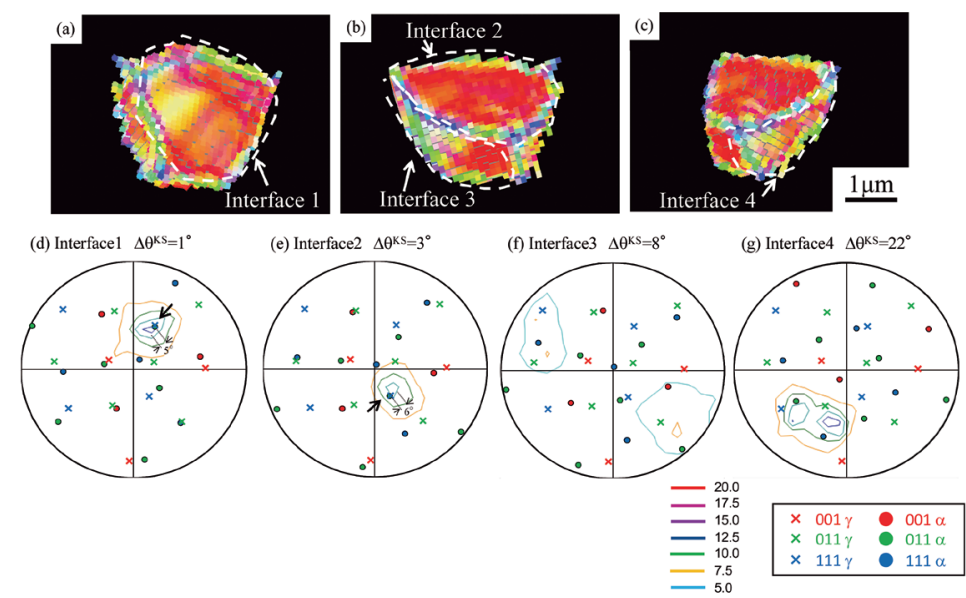

Received on Oct. 2, 2020; Accepted on Nov. 11, 2020 ; originally published in ISIJ Int., Vol.58, 2018, No.4, pp.742-750

* Corresponding author. E-mail : hata.pq3.kengo@jp.nipponsteel.com, Address : Nippon Steel Corporation, 1-8 Fuso-Cho Amagasaki Hyogo 660-0891

(i) $\Theta 2021$ The Iron and Steel Institute of Japan. This is an open access article under the terms of the Creative Commons Attribution-NonCommercialNoDerivatives license (https://creativecommons.org/licenses/by-nc-nd/4.0/). 


\title{
三次元 EBSD 法とTEM 観察法による低炭素鋼の $a \rightarrow \gamma$ 変態の相界面の組織解析
}

\author{
畑 顕吾 $^{1)} *$. 藤原 知哉 ${ }^{1)} \cdot$ 河野 佳織 ${ }^{1)} \cdot$ 杉山 昌章 ${ }^{2)} \cdot$ 福田 隆 ${ }^{2)}$. 掛下 知行 ${ }^{2,3)}$
}

Three-dimensional EBSD Analysis and TEM Observation for Interface Microstructure during Reverse Phase

Transformation in Low Carbon Steels

Kengo Hata, Kazuki Fujimara, Kaori Kawano, Masaaki Sugiyama, Takashi Fukuda and Tomoyuki KaKeshita

\section{1. 緒言}

鉄鋼材料に優れた機械的特性を付与するうえで熱処理 は重要なプロセスであり, 加熱と冷却によって起こる種々 の治金現象を利用し，金属組織を適切に制御することが 求められる。その中でも, 加熱過程で起こるフェライトか らオーステナイトへの相変態 $(\alpha \rightarrow \gamma$ 変態 $)$ は鉄鋼製品の 組織形成を大きく左右する現象の1つである。例えば, DP (デュアルフェーズ) 鋼の組織に含まれるマルテンサイト のサイズや形状を制御するには, 熱処理で二相温度域に昇 温された時のオーステナイトの形成を制御することが必 要である。そのオーステナイト粒成長過程では, 母相フェ ライトとの結晶学的関係が界面の易動度に影響すること によって，成長方向に異方性が生じると考えられる。した がって, 界面の易動度に強く関与する相界面の整合性に着 目する必要がある。このように, $\alpha \rightarrow \gamma$ 変態に関して相界 面の性質を理解することは，さまざまな鉄鋼製品の組織を 制御する上で必要であり，また，材料科学の基礎を深める 点でも重要である ${ }^{1-6)}$ 。

フェライトとオーステナイトの相界面の整合性は, Kurdjumov-Sachs（K-S）の関係 ${ }^{18)}$ や Nishiyama-Wasserman $(\mathrm{N}-\mathrm{W})$ の関係 ${ }^{19)}$ 等の特定の結晶方位関係と関連付けた研 究がなされている ${ }^{7-17)}$ 。例えばAaronsonらは, bcc 相とfcc 相の界面で接する原子について, 格子点の幾何学的な位置 関係をコンピュータ上で計算し, 両相が $\mathrm{N}-\mathrm{W}$ 関係や $\mathrm{K}-\mathrm{S}$ 関係といった結晶方位関係を満たすとき, 界面に部分的に 整合な原子構造を満たす領域が周期的に現れることを予測 している。

さらに近年の結晶方位関係に関する研究では, 加熱過程 で生成するオーステナイト相が複数の母相フェライト粒
との間で特定の結晶方位関係を満たすことが報告されて いる 20-31)。Lischewski とGottstein は，マイクロアロイ元素 を含む $\mathrm{C}-\mathrm{Mn}$ 鋼の $\alpha \rightarrow \gamma$ 変態を高温その場電子後方散乱回 折 (EBSD) 解析により観察し, 母相フェライトとオース テナイト粒の結晶方位関係を解析した ${ }^{28,29)}$ 。その結果，変 態オーステナイト粒は 2 つ上の隣接母相フェライト粒と $\mathrm{K}-\mathrm{S}$ 関係に近い結晶方位関係を満たすことを明らかにし た。

本研究の著者らも, 低炭素鋼の加熱過程の $\alpha \rightarrow \gamma$ 変態を 高温その場 EBSD解析，および三次元 (3D) EBSD解析によ り測定し，オーステナイトと隣接するフェライト粒との方 位関係の頻度を解析した ${ }^{30,31)}$ 。相変態で生成するオーステ ナイト粒の周囲のフェライトに対する粒間の方位は，1つ

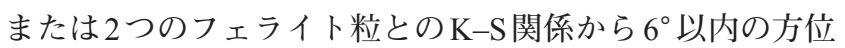
関係，さらに，別の隣接するフェライト粒とは $12^{\circ}$ 以内の $\mathrm{K}-\mathrm{S}$ 関係に近い方位関係を持つ事を確かめている。

これらの研究結果に基づくと, $\alpha \rightarrow \gamma$ 変態の初期段階に 打いてオーステナイト粒と複数のフェライト結晶粒との 界面で K-S 関係に近い方位関係が満たされることで, 上述 したように整合性の高い界面が形成されることと予想さ れる。そのような界面に扎いて易動度が低下することで, オーステナイトの粒成長挙動に異方性が生じる可能性があ る ${ }^{32-36)}$ 。このように, オーステナイトの相変態時に成立す る結晶方位関係と界面構造が, その後のオーステナイトの 結晶成長挙動に影響を及ぼすと考えられる。

本研究では, 鋼の二相温度におけるオーステナイトの組 織形成を理解するために， $\alpha \rightarrow \gamma$ 変態の初期にフェライト 粒界から生成するオーステナイトについて，隣接フェライ 卜粒との結晶方位関係とその界面の性質を研究することと した。二相温度域のフェライトとオーステナイトの三次元

原著論文：ISIJ Int., Vol.58 (2018), No.4, pp.742-750

2020 年 10 月 2 日受付 2020 年 11 月 11 日受理 (Received on Oct. 2, 2020; Accepted on Nov. 11, 2020 ; originally published in ISIJ Int., Vol.58, 2018, No.4, pp.742-750)

1）日本製鉄 (株) 先端技術研究所 (Advanced Technology Research Laboratories, Nippon Steel Corporation)

2) 大阪大学工学研究科 (Department of Materials Science and Engineering, Osaka University)

3) 福井工業大学 (Fukui University of Technology)

* Corresponding author. E-mail : hata.pq3.kengo@jp.nipponsteel.com, Address : Nippon Steel Corporation, 1-8 Fuso-Cho Amagasaki Hyogo 660-0891 
金属組織を研究するため, 急冷によりその焼入れ組織を得 た上で三次元EBSD解析を実施し，マルテンサイトから旧 オーステナイト粒を再構築する方法を適用した。さらに界 面の微視的状態を明らかにするため, 焼入れ組織中のマル テンサイトを透過型電子顕微鏡（TEM）で観察し，フェラ イトとマルテンサイトの界面の性質を結晶学的に考察し た。

\section{2. 実験方法}

Fe-1.0Mn-0.1C (mass\%) 合金を真空誘導炉で溶解し, 50 $\mathrm{kg}$ のインゴットを鋳造した。熱間圧延で厚さ $2 \mathrm{~mm}$ の鋼板 とし, 水噴霧により $710^{\circ} \mathrm{C}$ まで泠却した後, 炉に装入して $20^{\circ} \mathrm{C} / \mathrm{h}$ の冷却速度で室温まで冷却した。この鋼板を冷間圧 延で $1 \mathrm{~mm}$ の厚さにし, 板の中央部分から $200 \times 10 \times 1 \mathrm{~mm}^{3}$ の寸法の試験片を切り出した。試験片を $5^{\circ} \mathrm{C} / \mathrm{s}$ の速度で $730^{\circ} \mathrm{C}$ に加熱し, 保持を行うことなく高圧の水噴霧を使用 して $1000^{\circ} \mathrm{C} / \mathrm{s}$ を超える速度で室温へ冷却した。熱处理され た試験片から TEM観察用の試料を切り出し, 機械研磨に よって $0.1 \mathrm{~mm}$ 未満の厚さに薄片化した。その後直径 $3 \mathrm{~mm}$ のディスクに打ち抜き， $5 \%$ の過塩素酸と $95 \%$ の酢酸の電 解液を使用した一般的な電解研磨法 (Struers社 テヌポール -5）によって薄片試料とした。観察には, $200 \mathrm{kV}$ の日立製 電顕HF-2000（FE-TEM）を使用した。

3D-EBSD解析の試料は同じ熱処理された試験片から採 取しているが，この試料作製に先立って，試料に含まれる マルテンサイトの鮮明な菊池バンドパターンを得るため に $400^{\circ} \mathrm{C}$ で 1 時間焼き戻した。この $400^{\circ} \mathrm{C}$ の低温焼戻しによ り, ラスマルテンサイトの結晶情報に変化が生じないこと は組織観察から確認している。試料の表面はまず機械的 に研磨し, 次いでコロイドシリカ懸濁液で化学的に研磨し た。

3D-EBSD解析には, Gaイオンビームカラムと EBSD検 出器を備えたFEI Quanta 3D FEGを使用した ${ }^{31}$ 。測定シス テムの模式図をFig.1に示す。試料は, $54^{\circ}$ のプレチルトホ

(a) Geometry in the ion-milling position

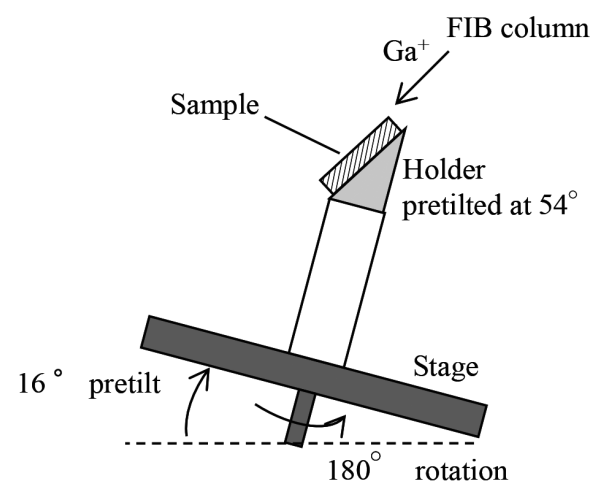

ルダーに据え付けられており, 水平位置から逆方向に $16^{\circ}$ 傾けたステージに取り付けた。この幾何学的配置によっ て, 垂直から $38^{\circ}$ の角度で取り付けられたイオンビームカ ラムによって, 観察面に平行な入射条件でイオンミリング を行った。ミリング位置から EBSD位置への移動はステー ジを $180^{\circ}$ 回転させることで行い, その後, 測定領域の周辺 にミリングされたマーカーを検出して，ステージをユーセ ントリック位置に自動調整した。試料のスライス加工は, $30 \mathrm{keV}$ で加速された $\mathrm{Ga}^{+}$イオンビームのスパッタリングに よって $0.1 \mu \mathrm{m}$ の厚さのステップで行った。スパッタされた $27 \times 40 \mu \mathrm{m}^{2}$ の領域でEBSD解析を行った。EBSD解析はス テップサイズ $80 \mathrm{~nm}$ の長方形スキャングリッドで行った。 EBSD データセットには, 測定中の X, Y 平面方向の試料ド リフトにより隣接するセクション間に僅かな位置ずれを 含んでいる。三次元のEBSDマップを正確に位置合わせす るために, EBSDマップ内のオイラー角とその位置 $(\mathrm{X}, \mathrm{Y})$ を使用した計算方法によって各画像の位置ずれを補正し

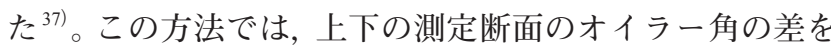
比較し，隣接する上下の断面像 (スライス像) の間でオイ ラー角の差が最小になるようにEBSDデータの位置を修正 した。

高温その場EBSD解析に使用する鋼の化学組成は, 高温 での Mnの蒸発を避けるために, $\mathrm{Fe}-0.2 \mathrm{C}$ (mass\%) を選定し た。冷間圧延した鋼板から $5 \times 7 \mathrm{~mm}$ の試験片を切り取り， 表面を機械的に研磨して厚さ $0.8 \mathrm{~mm}$ にした後, 電解研磨 した。高温その場EBSD解析は, TSLソリューションズ製 の加熱ステージを備えたFE-SEM (FEI Quanta 200 FEG) を 使用し, $680 \sim 840^{\circ} \mathrm{C}$ の温度範囲で $\mathrm{EBSD}$ 解析を行った。

\section{3. 実験結果}

\section{$3 \cdot 1 a \rightarrow \gamma$ 変態中のオーステナイト結晶粒成長の高温その場 EBSD 解析}

高温その場EBSD解析を使用して $\mathrm{Fe}-0.2 \mathrm{C}$ 合金の $\alpha \rightarrow \gamma$ 変態の組織形成を直接観察した。 $730^{\circ} \mathrm{C}$ から $840^{\circ} \mathrm{C}$ 一昇温 (b) Geometry in the EBSD position

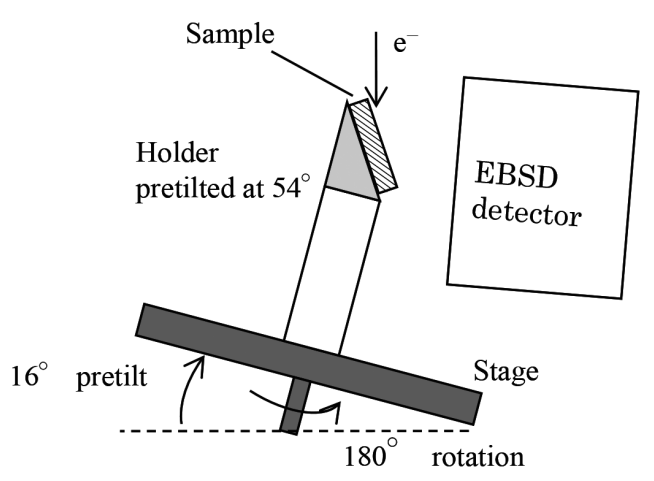

Fig. 1. Schematic of the geometry of the 3D-EBSD analysis setup. 
した時のオーステナイト粒の成長を Fig.2 (a)〜 (d) に示 す。同図は，フェライト粒をEBSD法で測定される菊池バ ンドの鮮明度を表すグレースケール画像 (Image Quality 像) で示し，その上でオーステナイト粒を赤色で表示して いる。 $730^{\circ} \mathrm{C} の$ 組織はフェライトとオーステナイトからな り，オーステナイト粒はフェライト粒の三重点に現れてい る。さらに温度が上昇するに伴って，オーステナイトは隣 接するフェライト粒に向かって成長し，最終的には $840^{\circ} \mathrm{C}$ で観察領域全体がオーステナイト相に変態した。次にFig.2

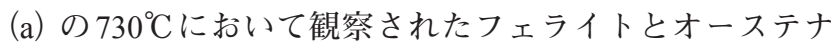
イトの結晶方位関係を解析した。結晶方位関係の評価法に ついては次節で詳細を述べるが，オーステナイト粒と正確 に K-S 関係を満たすフェライトの結晶方位に対して，測定 したフェライトの結晶方位との方位差を $\Delta \theta^{\mathrm{KS}}$ と定義した。 Fig.2 (a) の結晶粒 $\mathrm{A} \sim \mathrm{D}$ の結晶方位関係を Table 1 にまとめ た。同表には $730^{\circ} \mathrm{C}$ か $790^{\circ} \mathrm{C}$ へ昇温したときの各界面の移 動距離も示している。オーステナイト結晶粒Dの Interface 2 の方位関係は $\mathrm{K}-\mathrm{S}$ 関係に近い $\left(\Delta \theta^{\mathrm{KS}}=1^{\circ}\right)$ が, $1 \mu \mathrm{m}$ 未満 しか移動しなかった。一方, Interface 1，3，4，5の方位関係 はK-S 関係から $9^{\circ}$ 以上ずれているが，これらの界面は同じ 条件で $1 \mu \mathrm{m}$ 以上移動した。このように, K-S 関係を満たす 界面は移動距離が小さく，方位関係が $\mathrm{K}-\mathrm{S}$ 関係に対して $9^{\circ}$ を超える界面は移動距離が大きい。なおこの測定は試料表 面の二次元的観察に基づいて行っており，実際の三次元的 な界面移動を観察していない点には注意を要するが, Table 1 に示す結果は, 先行研究の結果と一致していることが確 認できる ${ }^{31)}$ 。

\section{$3 \cdot 2$ 3D-EBSD 解析による相界面の方位解析}

$\mathrm{Fe}-1.0 \mathrm{Mn}-0.1 \mathrm{C}$ 合金を二相温度の $730^{\circ} \mathrm{C}$ に加熱し焼入れた 試料において, K-S 関係に近い結晶方位関係を満たす $\alpha / \gamma$ 界面の法線方位を 3D-EBSD 解析によって測定した。 $5^{\circ} \mathrm{C} / \mathrm{s}$ の加熱速度で二相温度領域の $730^{\circ} \mathrm{C}$ に加熱し, $1000^{\circ} \mathrm{C} / \mathrm{s}$ を 超える速度で急冷した試料の組織をEBSD解析した結果 から，フェライトの三重点にマルテンサイトが存在してい ることを確認した。このことから, Fe-1.0Mn-0.1C合金で も $730^{\circ} \mathrm{C} へ$ 加熱過程でフェライトの三重点にオーステナ イト粒が現れたことが分かる。これは，Fig.2（a）のその場 (b) $790^{\circ} \mathrm{C}$

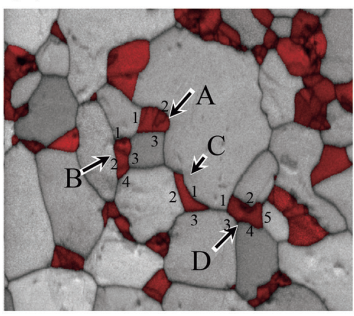

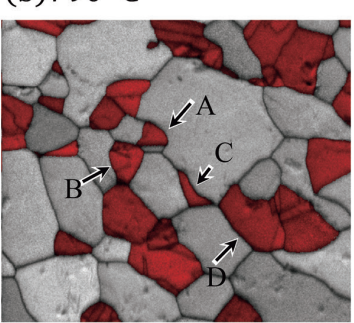

EBSD解析で観察された組織とほぼ同じであり, 両実験に 拈いて $\alpha \rightarrow \gamma$ 変態はフェライトの三重点から生じたことを 確認した。

$730^{\circ} \mathrm{C}$ から急冷された試料において，マルテンサイトと フェライトを含む典型的な局所領域を 3D-EBSD 解析法に より測定した。マルテンサイトからオーステナイトの結晶 方位を再構築する手順は以前の論文と同様であり ${ }^{31)}$ ，その 1 つの解析例を Fig.3の断面マップに示している。この解析 に用いた断面像の総数は70枚であり，同図には，そのうち の深さ $0.4,0.8,1.2,1.6,2.0$, および $2.4 \mu \mathrm{m}$ の断面で測定 した結晶方位マップを示している。マルテンサイト領域の 内部に数種類の異なる方位のピクセルが観察できる。これ は複数のマルテンサイトブロックが測定されたことを示 している。同図において黒色のピクセルは, 明確な菊池バ ンドパターンが得られなかった領域であるが，その面積率 は小さくマルテンサイトの一部と見做した。以上の結果か ら，マルテンサイトの領域とフェライト粒の間の界面は信 頼できる精度で測定されていることを確認した。

三次元の金属組織内のマルテンサイトブロックの方位

Table 1. Misorientation from the $\mathrm{K}-\mathrm{S}$ relationship and distance of interface migration between $730^{\circ} \mathrm{C}$ and $790{ }^{\circ} \mathrm{C}$.

\begin{tabular}{|c|c|c|c|}
\hline Austenite grain & $\begin{array}{l}\text { No. of interface } \\
\text { to adjacent } \\
\text { ferrite grain }\end{array}$ & $\begin{array}{l}\text { Misorientation } \\
\text { from the K-S } \\
\text { relationship, } \\
\Delta \theta^{\mathrm{KS}} \text { (deg.) }\end{array}$ & $\begin{array}{c}\text { Distance of } \\
\text { interface migration } \\
\text { between } 730^{\circ} \mathrm{C} \\
\text { and } 790^{\circ} \mathrm{C}(\mu \mathrm{m})\end{array}$ \\
\hline \multirow{3}{*}{ A } & Interface 1 & 3 & 0.4 \\
\hline & Interface 2 & 14 & 0.7 \\
\hline & Interface 3 & 1 & 0.9 \\
\hline \multirow{4}{*}{$\mathrm{B}$} & Interface 1 & 15 & 1.6 \\
\hline & Interface 2 & 15 & 1.7 \\
\hline & Interface 3 & 24 & 2.5 \\
\hline & Interface 4 & 31 & 1.8 \\
\hline \multirow{3}{*}{$\mathrm{C}$} & Interface 1 & 3 & 0.4 \\
\hline & Interface 2 & 1 & 0.5 \\
\hline & Interface 3 & 15 & 0.7 \\
\hline \multirow{5}{*}{$\mathrm{D}$} & Interface 1 & 9 & 1.3 \\
\hline & Interface 2 & 1 & 0.4 \\
\hline & Interface 3 & 26 & 2.5 \\
\hline & Interface 4 & 9 & 8.4 \\
\hline & Interface 5 & 19 & 1.8 \\
\hline
\end{tabular}

(c) $810^{\circ} \mathrm{C}$

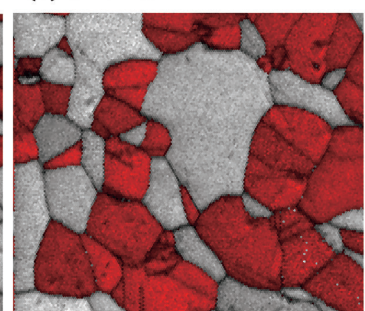

(d) $8400^{\circ} \mathrm{C}$

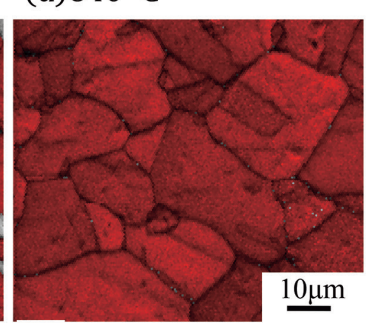

Fig. 2. Microstructure measured by in situ EBSD at different temperatures during the reverse transformation in Fe- $0.2 \mathrm{C}$ alloy (the ferrite microstructure is indicated by gray scale image representing the quality of Kikuchi band patterns and the austenite grains are shown in red color) ${ }^{311}$. 
データを使用して，旧オーステナイトの結晶方位を解析し た。その解析方法の詳細は過去に報告しているので省略す $3^{31,38-44)}$ 。著者らの以前の研究 ${ }^{31)}$ では, 再構築したオース テナイト結晶粒の方位を用いて，周囲の隣接フェライト粒 と特定の結晶方位関係を満たす頻度を解析したが, 本研究 では界面そのものの結晶学的特徵に焦点を当て, 界面を三 次元的に捉えてその法線方位を解析する。まず, 界面で接 するフェライトとオーステナイトの結晶方位関係は, K-S 関係からの方位差 $\Delta \theta^{\mathrm{KS}}$ として, 次の式 (1) と (2)で評価する。

$$
\mathbf{M}=\mathbf{g}^{\alpha}\left(\mathbf{R}_{\mathrm{j}} \mathbf{V}_{\mathrm{i}}^{\mathrm{KS}} \mathbf{g}^{\gamma}\right)^{-1}
$$

$$
\Delta \theta^{\mathrm{KS}}=\cos ^{-1}((\mathrm{M}[1,1]+\mathrm{M}[2,2]+\mathrm{M}[3,3]-1) / 2)
$$

ここでMは, 再構築したオーステナイトの結晶方位と正 確に $\mathrm{K}-\mathrm{S}$ 関係を満たす理想的なフェライト方位から, 測定 されたフェライト方位への回転行列を表わす。 $\mathbf{V}_{\mathrm{i}}^{\mathrm{KS}}(\mathrm{i}=1$ ‥24）は，正確な K-S関係による回転行列を表し，これは オーステナイト結晶座標系の $<112>$ を軸として $90^{\circ}$ 回転さ せる行列で表現できる。 $\mathbf{g}^{y}$ と $\mathbf{g}^{\alpha}$ は，それぞれ旧オーステナ イトと隣接フェライトの結晶方位を表し, 試料座標系から 各相の結晶座標系への回転行列として定義している。 $\mathbf{R}_{\mathrm{j}}(\mathrm{j}$ $=1 \cdots 24)$ は, bcc 結晶の対称性に関する回転行列である。 回転行列 $\mathbf{M}$ の指数 $[i, i](i=1 \cdots 3)$ は, $3 \times 3$ 行列の対角成 分を表す。

三次元再構築した金属組織において，オーステナイト粒 のほとんどは4つまたは5つのフェライト粒に隣接してい た。これは，オーステナイトが母相フェライトの粒界コー ナーで核生成したことを示している。三次元組織から代表 的なオーステナイト粒を1つ抽出した例を Fig.4に示す。こ のオーステナイト粒は, Fig.3 (a)〜3 (f) に示したマルテン サイトの領域から再構築したものである。Fig.4 (a) 〜 4 (c) の界面のボクセルの色は, 各ボクセルに打ける界面のサン プル座標系に打ける法線方向を表している ${ }^{35)}$ 。同図 (a) の オーステナイト粒は5つのフェライト粒との間に界面を持 ち，これらの界面で隣接するフェライト粒との結晶方位関 係を $\mathrm{K}-\mathrm{S}$ 関係からの方位差 $\Delta \theta^{\mathrm{KS}}$ で表すとそれぞれ $2^{\circ} ， 6^{\circ}$ ， $14^{\circ}, 20^{\circ}, 28^{\circ}$ である。

この界面法線の計算方法を簡潔に説明する。ボクセルで 構成された三次元組織において界面の法線べクトルを求 めるには, 界面上での着目したボクセルからの前後左右に 存在するボクセルを結ぶ位置ベクトルを設定し，それらの ベクトルの外積を求めてその平均を取ることで, 着目した ボクセルの法線方向とすることで評価した。すなわち Fig.4 (b) に模式的に示すように, 中心のボクセルに打ける局所 的な法線方向 $\boldsymbol{n}_{\mathrm{s}}$ を決定するには，まず中心ボクセルから隣 接ボクセルへ延びる8つのべクトル $\mathbf{x}_{1}-\mathbf{x}_{8}$ を設定する。 $\mathbf{x}_{1}-\mathbf{x}_{8}$ のベクトルから隣り合う2つの組み合わせをすべて選んで 外積方向ベクトルを求め，その平均を次のように与える。

$$
\boldsymbol{n}_{\mathrm{s}}=\frac{1}{8} \sum_{\mathrm{i}=1}^{8} \frac{\mathbf{x}_{\mathrm{i}} \times \mathbf{x}_{\mathrm{i}+1}}{\sqrt{\left|\mathbf{x}_{\mathrm{i}}\right|^{2}\left|\mathbf{x}_{\mathrm{i}+1}\right|^{2}-\left|\mathbf{x}_{\mathrm{i}} \cdot \mathbf{x}_{\mathrm{i}+1}\right|^{2}}}
$$

なお式 (3) の $\mathrm{i}=8$ の場合に現れるべクトル $\mathbf{x}_{9}$ は $\mathbf{x}_{1}$ と等 しい。上記の説明は，中心のボクセルの第 1 近接のボクセ ルのみを使用した計算を示しているが，実際の計算では界 面法線をより正確に評価するために，第2近接のボクセル まで考慮して計算した。この3D-EBSD解析による界面法 線の決定法に関しては，ボクセルのサイズが比較的大きい ( $0.1 \mu \mathrm{m})$ ことを考慮すると, その1つのボクセル単位で の方向精度は必ずしも高いとは言えない。しかしながら， この計算では界面を構成する多数のボクセルから法線べ クトルの集合を求め，その平均の方向を求めることから， 統計的な法線方向の最頻值, つまり最も頻度が高い法線方 向べクトルを求めることができる。また，法線べクトルの 分散状態から界面の曲率を知ることができる。これによっ て, 実空間に打ける界面法線の最頻值を，フェライトおよ びオーステナイトの結晶方位と比較して議論することが可 能となる。

1つのマルテンサイト領域を例に, 界面解析を行った結 果を Fig.5の極点図に示す。同図 (d) 〜 (f) では, 界面法線 の分布を等高線で表している。さらに, オーステナイトの $\{001\}_{y},\{011\}_{y}$ ，および\{111\},の法線方向を，それぞれ赤色，緑 色, 青色の十字のプロットで表し, オーステナイトに隣接 するフェライト粒の $\{001\}_{\alpha},\{011\}_{\alpha}$ ，および $\{111\}_{\alpha}$ の法線方向 を，同じ色の円のプロットで表している。極点図の縦軸と 横軸は，それぞれ三次元構築した直方体の試料の基準とな る2つの稜線に平行に打いた。

Fig.5の解析結果からフェライトとオーステナイト界面 の法線方位は次の通りである。Interface 1で接するフェラ イト相とオーステナイト相の $\mathrm{K}-\mathrm{S}$ 関係からの方位差は $\Delta$ $\theta^{\mathrm{KS}}=1^{\circ}$ であり, K-S 関係に非常に近い方位関係を満たし ている。これらのフェライト相とオーステナイト相の平行 な最密面 $\left(\{111\}_{y} / /\{011\}_{a}\right)$ の法線方向は, Fig.5 (d) の極点 図に打いて矢印に示す方向である。等高線で示される界面 法線の分布を見ると，その最頻值の位置は上述の最密面の 法線方向に非常に近く，その方位差は約 50 である。つまり 界面の法線方向は, \{111 $\}_{y} / /\{011\}_{\alpha}$ の法線方向とほぼ同じ方 向を向いている。次にInterface 2を見ると，フェライト相 とオーステナイト相の $\mathrm{K}-\mathrm{S}$ 関係からの方位差は $\Delta \theta^{\mathrm{KS}}=3^{\circ}$ であり，この場合も K-S関係に近い方位関係を満たして いる。そして，Fig.5（e）に示すように界面法線の最頻值と 矢印で示す最密面法線の間の方位差は約 $6^{\circ}$ である。すな わち, この界面に打いても法線方向は最密面の法線方向 とほぼ同じ方向を向いている。一方, Fig.5 (f) と5 (g) の Interface 3 と 4 に打いては, 結晶方位関係はそれ无れ $\mathrm{K}-\mathrm{S}$ 関 係から $8^{\circ}$ および $22^{\circ}$ の方位差を持つ。これらの界面の法線 方向は，フェライト相打よびオーステナイト相の最密面か 
ら大きく外れた方向を向いている。

再現性を確かめるために，このような解析を別のオース テナイト粒についても行った。その結果を Fig.6に示す。同 図のオーステナイト粒は, Interface 1 と2でそれぞれ $\Delta \theta^{\mathrm{KS}}$ $=6^{\circ}$ および $11^{\circ}$ の方位差を持ち $\mathrm{K}-\mathrm{S}$ 関係に近い界面であ る。これらの界面の法線はFig.6 (d) および6 (e) に示すよ うに最密面法線に近い方向を向いており，その方位差は〜 $17^{\circ}$ および〜 $24^{\circ}$ である。一方, Fig.6 (f) および6 (g)の K$\mathrm{S}$ 関係から逸脱した方位関係を持つ Interface 3 と 4 では, 界 面法線と最密面の法線の間に一致は見られない。この結果 は, Fig.5のオーステナイト粒のInterface 3, 4の結果と一致 している。
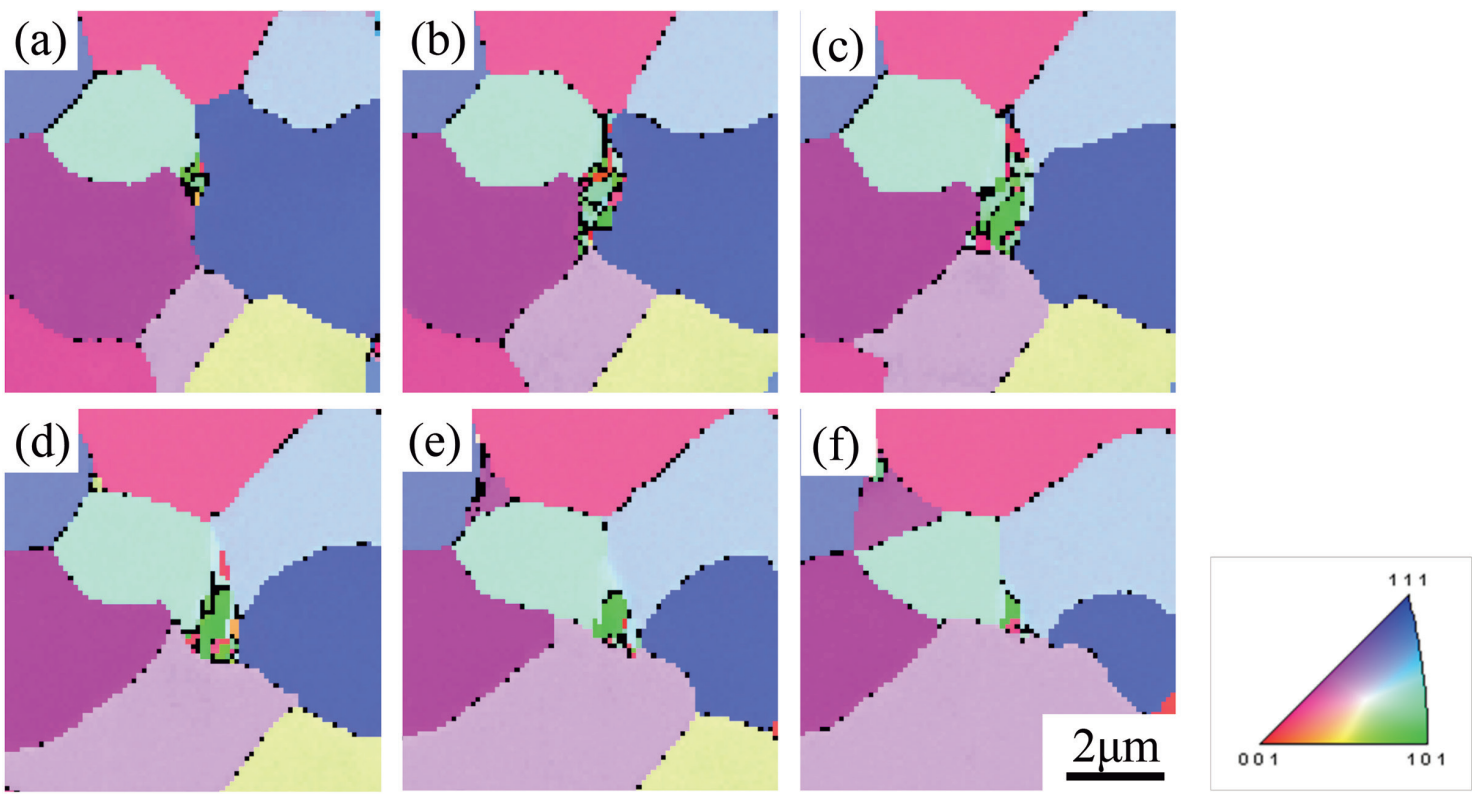

Fig. 3. A series of orientation mappings of martensite in $\mathrm{Fe}-0.1 \mathrm{C}-1 \mathrm{Mn}$ alloy quenched from $730^{\circ} \mathrm{C}$ in the heat treatment, measured at a depth of (a) $0.4 \mu \mathrm{m}$, (b) $0.8 \mu \mathrm{m}$, (c) $1.2 \mu \mathrm{m}$, (d) $1.6 \mu \mathrm{m}$, (e) $2.0 \mu \mathrm{m}$, (f) $2.4 \mu \mathrm{m}$ (the color indicates the crystal orientation, which corresponds to the attached standard stereo triangle).
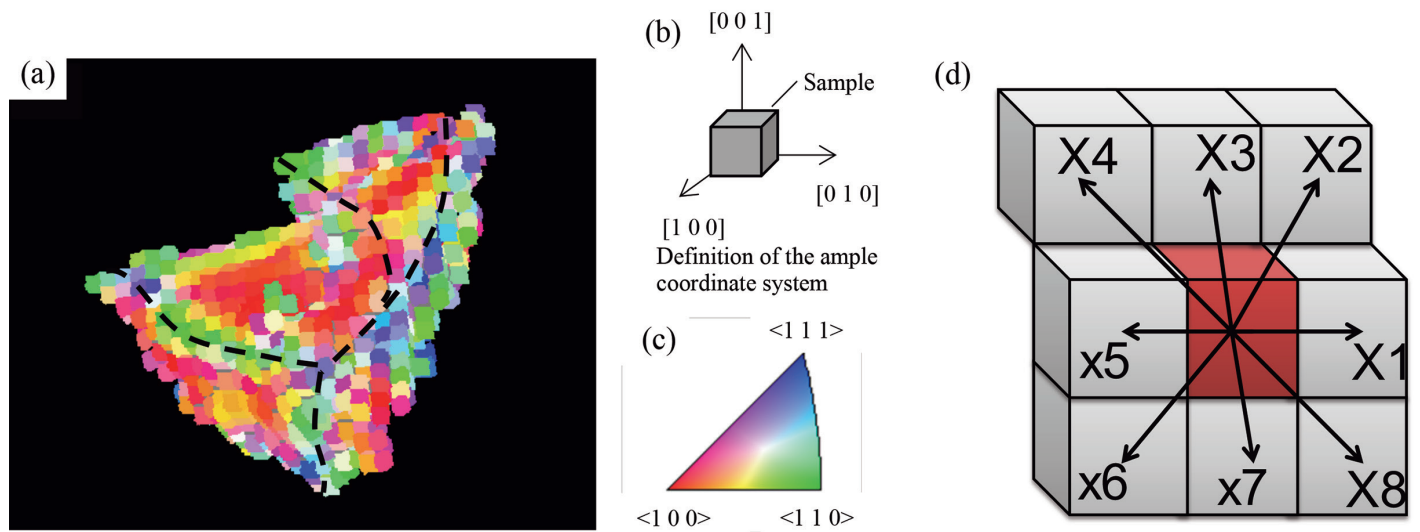

Fig. 4. (a) A reconstructed austenite grain (martensite region) in Fe-0.1C-1Mn alloy reconstructed from the EBSD data of martensite blocks shown in Fig. 3(a)-(f) (the broken black lines are superimposed along the grain edge of the prior austenite to clarify its morphology),

(b) definition of the sample coordinate system,

(c) the color code on the surface indicating the grain boundary normal in the sample coordinate system,

(d) schematic for analysis method of boundary plane normal based on the voxel model, displaying a voxel of interest and eight voxels in first neighbor on surface as well as eight vectors for calculating the normal vector. 

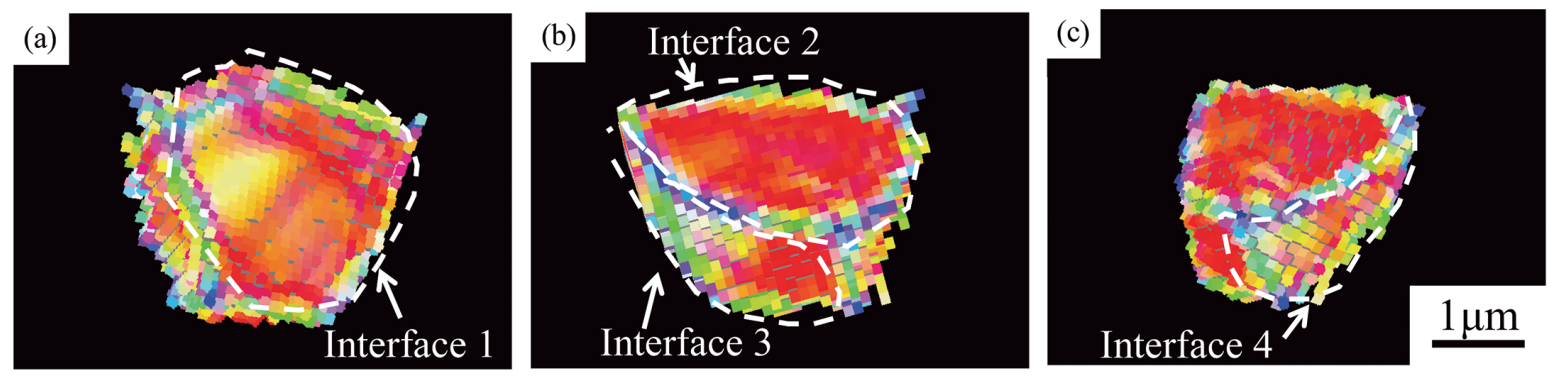

(d) Interface1 $\Delta \theta^{\mathrm{KS}}=1^{\circ}$

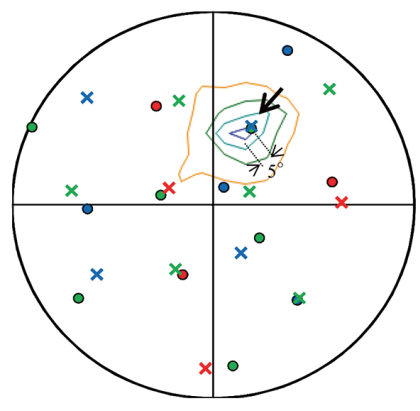

(e) Interface $2 \Delta \theta^{\mathrm{KS}}=3^{\circ}$

(f) Interface $3 \Delta \theta^{\mathrm{KS}}=8^{\circ}$

(g) Interface $4 \Delta \theta^{\mathrm{KS}}=22^{\circ}$
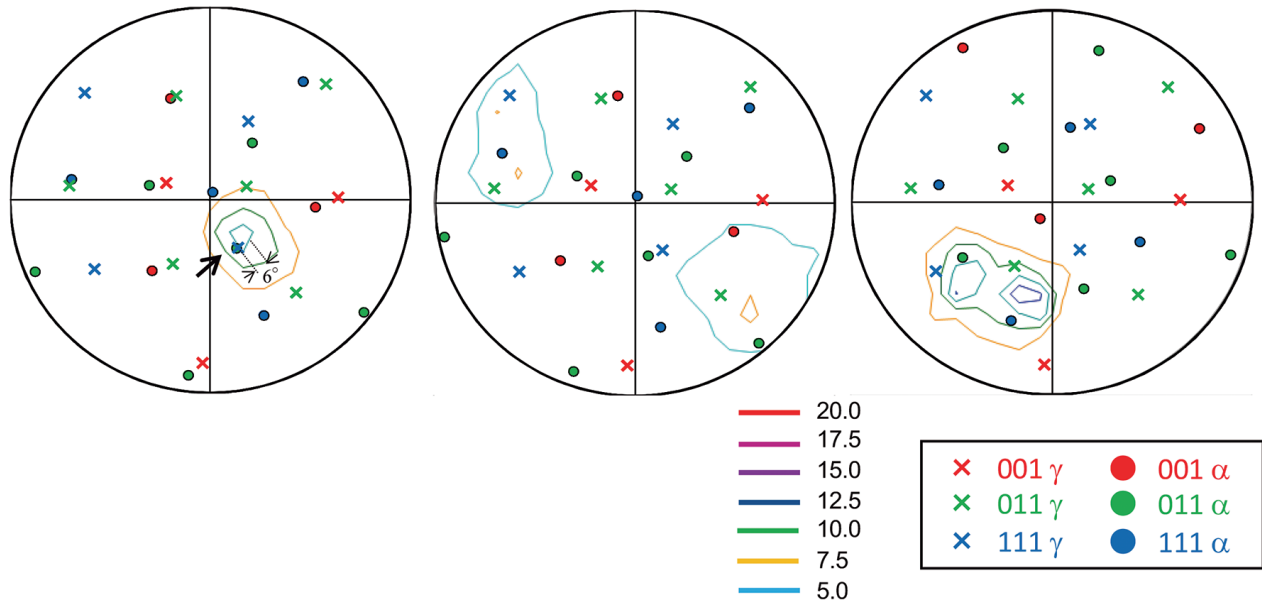

Fig. 5. A three-dimensional morphology of an austenite grain (martensite region in the sample quenched from $730^{\circ} \mathrm{C}$ ) and the analysis on the grain boundary normals at different interfaces in Fe-0.1C-1Mn alloy: (a)-(c) A reconstructed austenite grain observed from three different directions (the broken white lines are superimposed along the grain edge of the prior austenite to clarify the interfaces to different ferrite grains), (d)-(f) pole figures indicating the grain boundary normal as the contour map and the orientations for ferrite and austenite, each contour line corresponds to the pole density of boundary normal vectors by 2.5 times to random distribution of an assumed spherical interface.
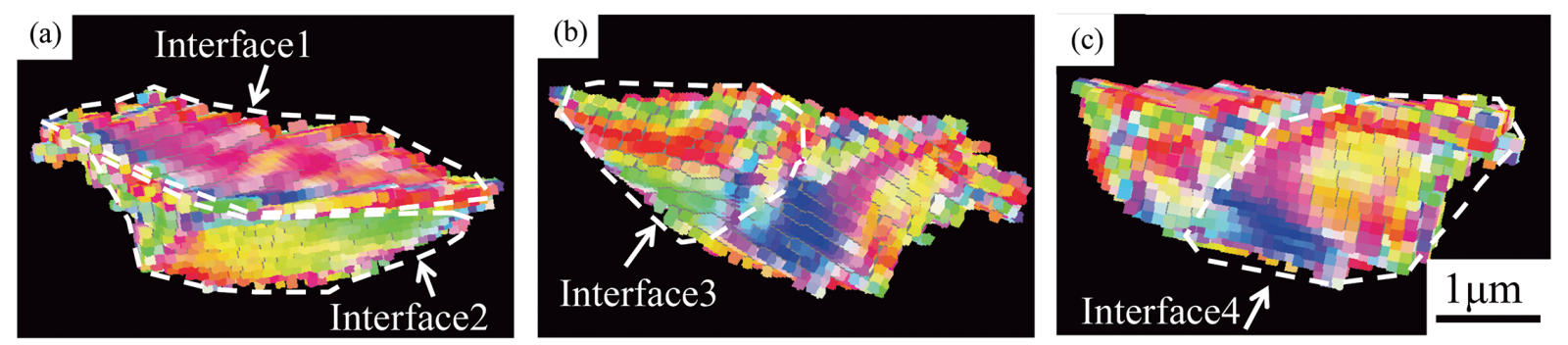

(d) Interface $1 \quad \Delta \theta^{\mathrm{KS}}=6^{\circ}$

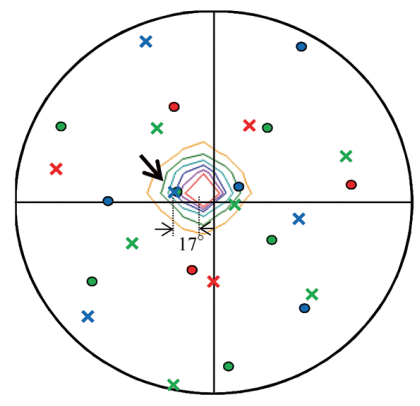

(e) Interface $2 \Delta \theta^{\mathrm{KS}}=11^{\circ}$

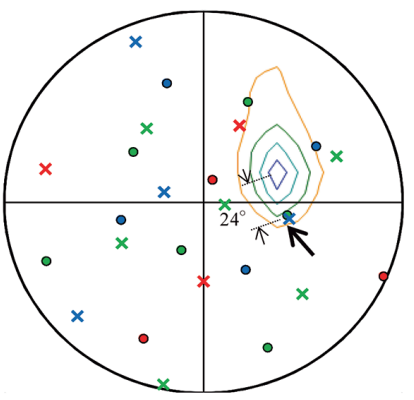

(f) Interface $3 \Delta \theta^{\mathrm{KS}}=22^{\circ}$
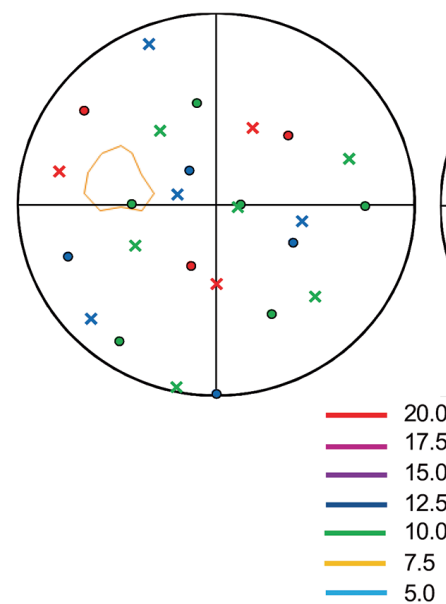

(g) Interface $4 \Delta \theta^{\mathrm{KS}}=27^{\circ}$
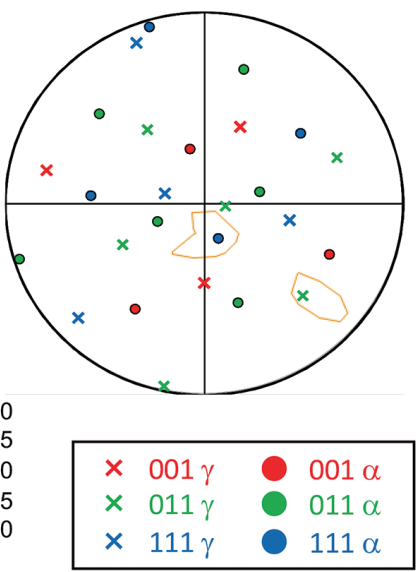

Fig. 6. A three-dimensional morphology of an austenite grain (martensite region in the sample quenched from $730^{\circ} \mathrm{C}$ ) and the analysis on the grain boundary normals at different interfaces in Fe-0.1C-1Mn alloy. 
の $\mathrm{K}-\mathrm{S}$ 関係から 6〜 12 ずれた56の界面については，その 60\%（つまり33の界面）が $\{111\}_{y}$ または $\{011\}_{\alpha}$ の近くにあつ た。

\section{$3 \cdot 3$ オーステナイト粒界面のTEM 観察}

$\alpha \rightarrow \gamma$ 変態初期のオーステナイトの形成とその成長過程 において，K-S 関係に近い方位関係を満たす界面が及ぼす 影響は重要である。界面の微視的状態を知るため, 熱処理 で $730^{\circ} \mathrm{C}$ から急冷した試料のマルテンサイトの組織を室温 でTEMにより観察した。その観察から，ほとんどのマルテ ンサイト領域は母相フェライトの粒界三重点に存在するこ とを改めて確認できた。またマルテンサイトの内部または その境界にはセメンタイトは観察されず，セメンタイト粒 子の殆どはフェライトの粒内またはオーステナイト粒界と は関係のないフェライト粒界に存在していることを確認し た。前の研究に打いてもオーステナイトへの変態前の組織 を観察しているが ${ }^{31)}$ ，セメンタイト粒子はフェライトの粒 界三重点に特に偏在していることはなく，フェライト粒内 を含めて組織内にランダムに分散していた。このため，初 期のオーステナイト粒が粒界コーナーに形成されたとき， セメンタイトを起点としてオーステナイト粒が核生成した 可能性は低く，両者の間で核生成を容易とするような結晶 方位関係が成立する状態ではなかったと考えられる。

TEM観察からマルテンサイトの形態は転位を含むラス 構造を持つことを確認した。典型的な例として，マルテン サイトと周囲のフェライト粒を含む明視野像を Fig.7 に示 す。この観察から，マルテンサイトとFerrite grain 1の間の 界面は平坦であり，Fig.7 (a) に示すように，[311］電子線 入射の条件でエッジ入射条件を満たしている。Ferrite grain 1の011反射による暗視野像を Fig.7（b）に示すが，この観 察像に打いて界面のトレースはFerrite grain 1 の $[01 \overline{1}]_{\alpha}$ 方
向に垂直である。他の界面を見ると, Ferrite grain 2 おび 3 への界面もほぼ平坦であるが, Ferrite grain 4の界面は曲率 が大きく複雑な形状をとっている。

\section{4. 考察}

3D-EBSD解析により測定したフェライト粒とオーステ ナイト粒の界面について, 本研究ではボクセルの法線方向 ベクトルの決定法を提案した。この解析方法の妥当性を考 察する。マルテンサイトの界面が平滑でない場合は，オー ステナイト界面を再構築することは困難である。しかし， 低炭素鋼のラスマルテンサイトはオーステナイトの粒界か ら核生成することが知られていて，マルテンサイト相の成 長界面を除き，変態開始粒界となったオーステナイトの平 滑な界面は室温でも維持されると考えられる。実際にFig.7 (a) に示したように，フェライトとマルテンサイトの組織 に扎いて界面をTEMによって観察したところ，平滑な界 面を持つマルテンサイト領域が多数観察された。これらの 観測は3D-EBSD解析によって $\alpha / \gamma$ 界面を解析することの 妥当性を支持している。

Fig.5 と Fig.6のオーステナイト粒について, 結晶の最密 面と界面法線の方位差を Table 2 によめた。Fig. 5 のオー ステナイト粒 1 について, Interface 1 はフェライトとオース テナイトの晶㾕面と見做され， $\alpha \rightarrow \gamma$ 変態の初期段階で形 成されたものと考えられる。Fig.5 (e) の Interface 2 の場合 にも，界面法線の方向が (111) $\gamma / /(011)_{\alpha}$ の法線方向に近い 事が確認できる。以上から，K-S関係と N-W関係の方位関 係の間の方位関係を満たす界面は，フェライトとオーステ ナイトの最密面 $\left(\{111\}_{y} / /\{011\}_{\alpha}\right)$ の近傍にあると結論する ことができる。K-S関係から 6〜120ずれた方向関係を持つ
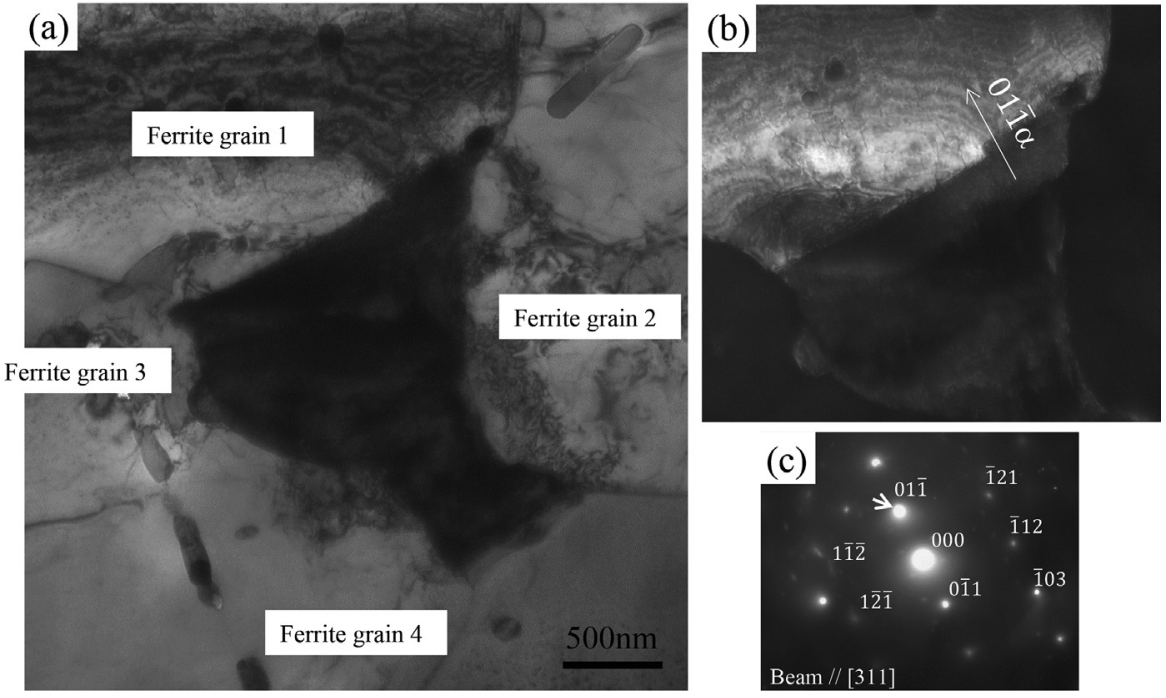

Fig. 7. TEM micrograph of ferrite-martensite microstructure and orientation analysis at the interface in Fe- $0.1 \mathrm{C}-1 \mathrm{Mn}$ alloy quenched from $730^{\circ} \mathrm{C}$ in the heat treatment (a) Bright-field image, (b) Dark-field image taken by $01 \overline{1}$ reflection from Ferrite grain 1 , (c) The diffraction pattern of $01 \overline{1}$ reflection from Ferrite grain 1. 
界面も，\{111\}または 011$\}_{\alpha} に$ に近い傾向がある。Fig.6 (d) お よびFig.6 (e) に示したように, 界面法線が $\{111\}_{y} / /\{011\}_{\alpha}$ の 最密面から少しずれた方向にあることは, 界面の重要な性 質を示していると考えられる。過去の研究では, K-S関係 や $\mathrm{N}-\mathrm{W}$ 関係などの特定の方位関係を持つ界面の構造を顕

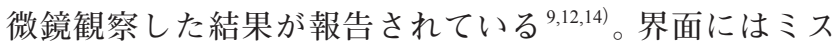
フィット転位の配列，ならびに，平行に配列した構造レッ ジが含まれ，見かけの晶壁面は $\{011\}_{\mathrm{bcc}} / /\{111\}_{\mathrm{fcc}}$ から大きく 外れると報告されている。本研究の3D-EBSD解析におい ても同様に, 界面が最密面からずれた方向にあることを確 かめている。

本研究の高温その場EBSD解析では, K-S関係に近い方 位関係を持つ界面はほとんど移動しなかった。それらの界 面の性質を明確にするために, フェライト相とオーステ ナイト相の最密面の方位差 $\Delta \theta_{\mathrm{cpp}}$, 打よび, 最密方向の方位 差 $\Delta \theta_{\mathrm{cpp}}$ を測定した。これらの方位差 $\Delta \theta_{\mathrm{cpp}}$ および $\Delta \theta_{\mathrm{cpp}}$ は, $<011>_{y}$ と $<111>_{\alpha}$, および $\{111\}_{y}$ と $\{011\}_{\alpha}$ の法線方向の中から 最も近い方向の組み合わせを選択し, 次の式を計算して求 めた。

$$
\begin{aligned}
& \Delta \theta_{\mathrm{cpp}}=\arccos \left(\left(\left(\mathbf{g}^{\gamma}\right)^{-1} \mathbf{P}_{\mathrm{cpp}}{ }^{\gamma}\right) \cdot\left(\left(\mathbf{g}^{\alpha}\right)^{-1} \mathbf{P}_{\mathrm{cpp}}{ }^{\alpha}\right)\right) \\
& \Delta \theta_{\mathrm{cpd}}=\arccos \left(\left(\left(\mathbf{g}^{\gamma}\right)^{-1} \mathbf{P}_{\mathrm{cpd}}{ }^{\gamma}\right) \cdot\left(\left(\mathbf{g}^{\alpha}\right)^{-1} \mathbf{P}_{\mathrm{cpd}}{ }^{\alpha}\right)\right)
\end{aligned}
$$

ここで， $\mathbf{P}_{\mathrm{cpp}}$ と $\mathbf{P}_{\mathrm{cpd}}$ は，それぞれ最密面の法線方向と最密 方向の結晶座標系でのべクトルである。2つの方位差の関 係を Fig.8に示す。同図は，高温その場EBSD解析に抋いて $730^{\circ} \mathrm{C}$ と $790^{\circ} \mathrm{C}$ の測定データの間で $1 \mu \mathrm{m}$ 以上移動した界面 を白抜きのプロットで示し, $1 \mu \mathrm{m}$ 未満しか移動しなかった 界面を黒色のプロットで示している。この結果から, 最密 面の方位差 $\Delta \theta_{\mathrm{cpp}}$ が $2^{\circ}$ 未満を維持しながら, 最密方向の方 位差 $\Delta \theta_{\text {cpd }}$ が $0^{\circ}$ から $5^{\circ}$ までを満たす界面が非常に多いこと が分かる。この方位関係は, K-S関係 $\left(\Delta \theta_{\text {cpd }}, \Delta \theta_{\text {cpp }}\right)=\left(0^{\circ}\right.$, $\left.0^{\circ}\right)$ と $\mathrm{N}-\mathrm{W}$ 関係 $\left(\Delta \theta_{\mathrm{cpd}}, \Delta \theta_{\mathrm{cpp}}\right)=\left(5.3^{\circ}, 0^{\circ}\right)$ の間の方位関 係に対応している。また, $\left(\Delta \theta_{\text {cpd }}, \Delta \theta_{\text {cpp }}\right)=\left(2.5^{\circ}, 2.0^{\circ}\right)$ の Greninger-Troianoの関係 ${ }^{45)}$ に近い方位関係も多い。明らか な傾向として, 易動度の低い界面は最密方向の間の方位差
よりも最密面の間の方位差が小さい方位関係を持つ傾向が ある。これらの特定の方向関係を持つ界面は，フェライト とオーステナイトの整合性の良い結晶面の組み合わせで構 成され，それによって界面の易動度が低くなっていること が示唆される。この傾向は, 3D-EBSD解析とTEM観察で 得られた結果とも一致している。このように, $\alpha / \gamma$ 界面が 選択的な結晶面からなる構造を持つことによって, 界面の 易動度を低下させていると予想される。

\section{5. 結論}

$\mathrm{A}_{\mathrm{cl}}$ 温度においてフェライト相から変態したオーステナ イト相の界面の結晶学的性質を, 室温へ焼き入れた後の フェライトーマルテンサイト組織に対する3D-EBSD解析 打よびTEM観察を通して研究した。3D-EBSD解析に扔い ては, マルテンサイトのバリアント解析による旧オーステ

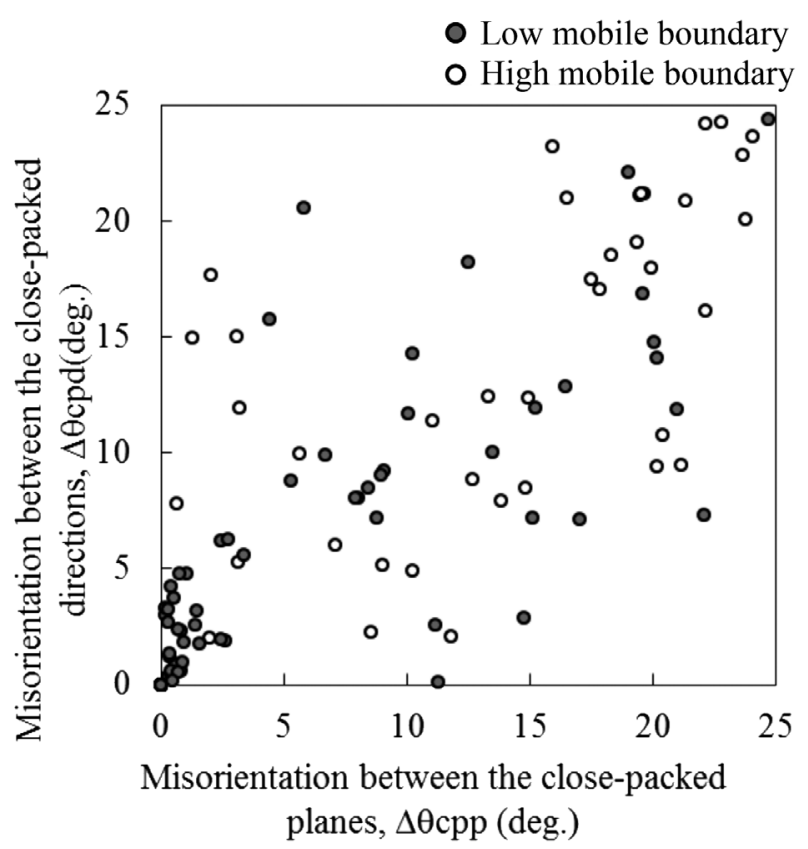

Fig. 8. The misorientation of the close-packed planes and closepacked directions at $\alpha / \gamma$ interfaces measured using in situ EBSD of Fe- $0.2 \mathrm{C}$ alloy.

Table 2. Orientation relationships and the deviation of grain boundary normal from the close-packed planes of the phases at each

\begin{tabular}{|c|c|c|c|c|c|c|}
\hline \multirow{2}{*}{$\begin{array}{c}\text { Austenite } \\
\text { grain }\end{array}$} & \multirow{2}{*}{ Interface } & \multirow{2}{*}{$\begin{array}{c}\text { Misorientation } \\
\text { from the K-S, } \\
\Delta \theta^{\mathrm{KS}} / \mathrm{deg} .\end{array}$} & \multirow{2}{*}{$\begin{array}{c}\text { Misorientation } \\
\text { between }\{111\} \gamma \text { and } \\
\{011\} a, \Delta \theta \text { cpp / deg. }\end{array}$} & \multirow{2}{*}{$\begin{array}{c}\text { Misorientation } \\
\text { between }<011>\gamma \text { and } \\
<111>a, \Delta \theta \mathrm{cpd} / \mathrm{deg} .\end{array}$} & \multicolumn{2}{|c|}{$\begin{array}{c}\text { Deviation of boundary normal from the } \\
\text { close-packed planes }\end{array}$} \\
\hline & & & & & \multicolumn{2}{|c|}{ Deviation /deg. Location to the c.p.p } \\
\hline 1 & Interface 1 & 0.8 & 0.4 & 0.8 & $\sim 5^{\circ}$ & In vicinity \\
\hline 1 & Interface 2 & 2.7 & 0.5 & 2.6 & $\sim 6^{\circ}$ & In vicinity \\
\hline 1 & Interface 3 & 8.0 & 7.7 & 7.0 & Large & Not related \\
\hline 1 & Interface 4 & 21.7 & 19.8 & 11.6 & Large & Not related \\
\hline 2 & Interface 1 & 6.3 & 0.8 & 6.2 & $\sim 17^{\circ}$ & In vicinity \\
\hline 2 & Interface 2 & 11.8 & 2.6 & 11.6 & $\sim 24^{\circ}$ & In vicinity \\
\hline 2 & Interface 3 & 22.1 & 16.7 & 18.4 & Large & Not related \\
\hline 2 & Interface 4 & 26.8 & 23.1 & 12.1 & Large & Not related \\
\hline
\end{tabular}
interface of two martensite regions (martensite region 1 and 2 correspond to those shown in Fig. 5 and 6, respectively). 
ナイト粒の結晶方位の再構築法を使って, 高温のオーステ ナイト組織を解析した。さらに, 高温でのオーステナイト 組織の形成を，高温その場EBSD法によって直接的に測定 した。これらの実験結果に基づいて， $\alpha / \gamma$ 界面の易動度と 界面の三次元組織の関係に関して以下の結論を得た。

（1）鋼の加熱過程において，フェライト相の三重点から オーステナイト粒が変態すると，オーステナイトの粒 界の1つまたは2つにおいて, K-S関係から僅かにず れた結晶方位関係が満たされ，その界面法線は最密面 $\{111\}_{\gamma} / /\{011\}_{\alpha}$ の法線方向の近傍にある。

(2) 3D-EBSD解析で測定した結晶粒の界面の性質を議論す るため, 界面上のボクセル間の位置べクトルの外積を 計算することにより界面法線方向を決定する方法を提 案した。

(3) フェライトーマルテンサイト組織を TEM観察した結 果から，マルテンサイトと隣接するフェライト粒との 間に平滑な界面が多いことが分かった。典型的な界面 のトレース方向は，フェライト粒の $[011]_{\alpha}$ に垂直であ る。この結果は, 3D-EBSD解析によって界面法線を解 析した結果と一致している。

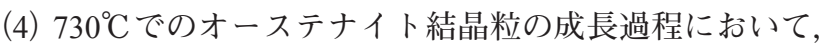
$\mathrm{K}-\mathrm{S}$ 関係に近い方位関係（許容方位差 $9^{\circ}$ 以内）を持つ $\alpha / \gamma$ 界面の易動度は著しく低下する。フェライトおよび オーステナイトの最密面の法線方向と最密方向は, $\mathrm{K}$ $\mathrm{S}$ 関係から $5^{\circ}$ 以内の条件を満たす。このような界面は, 特定の結晶面を持つ高い整合性を持つた構造を形成 し， $\alpha \rightarrow \gamma$ 変態のオーステナイトの粒成長において界 面の移動を抑制する因子の一つとなり得る。

\section{謝辞}

本研究で用いた結晶方位解析の計算方法について, 茨城 大学の富田俊郎博士から多くの貴重な議論の機会を頂きま した。ここに深く感謝いたします。日本製鉄 (株) の中川㳯 一博士とNSソリューションズの中村望氏には, 本研究で 適用した界面法線の解析法に関して貴重なご助言を多数頂 きました。厚く感謝の意を表します。

\section{文献}

1 ) G.R.Speich, V.A.Demarest and R.L.Miller: Metall. Trans. A, 12(1981), 1419.

2 ) D.Z.Yang, E.L.Brown, D.K.Matlock and G.Krauss: Metall. Trans. A, 16(1985), 1385

3 ) N.Nakada, T.Tsuchiyama, S.Takaki and S.Hashizume: ISIJ Int., 47(2007), 1527

4 ) T.Hara, N.Maruyama, Y.Shinohara, H.Asahi, G.Shigesato, M.Sugiyama and T.Koseki: ISIJ Int., 49(2009), 1792.

5 ) S.Watanabe and T.Kunitake : Tetsu-to-Hagané, 61(1975), 96 (in Japanese)

6 ) K.Ameyama, T.Maki and I.Tamura: J. Jpn. Inst. Met., 50(1986), 602 (in Japanese).
7 ) M.G.Hall, H.I.Aaronson and K.R.Kinsma: Surf. Sci., 31(1972), 257.

8 ) J.M.Regisbee and H.I.Aaronson: Acta Metall., 27(1979), 351.

9 ) J.M.Regisbee and H.I.Aaronson: Acta Metall., 27(1979), 365.

10) M.G.Hall, J.M.Rigsbee and H.I.Aaronson: Acta Metall., 34(1986), 1419.

11) U.Dahmen: Scr. Metall., 21(1987), 1029.

12) T.Furuhara, A.M.Dalley and H.I.Aaronson: Scr. Metall., 22(1988), 1509.

13) H.I.Aaronson, T.Furuhara, J.M.Regisbee, W.T.Reynolds, Jr. and J.M. Howe: Metall. Trans. A, 21(1990), 2369.

14) T.Furuhara and T.Maki: Mater. Trans. JIM, 33(1992), 734.

15) Q.Liang and W.T.Reynolds, Jr.: Metall. Mater. Trans. A, 29(1998), 2059.

16) T.Furuhara, K.Oishi and T.Maki: Metall. Mater. Trans. A, 33(2002), 2327.

17) T.Nagano and M.Enomoto: Metall. Mater. Trans. A, 37(2006), 929.

18) G.Kurdjumov and G.Sachs: Z. Phys., 64(1930), 325 (in German).

19) Z.Nishiyama: Sci. Rep. Tohoku Imp. Univ., 23(1934), 638.

20) K.Ameyama, T.Maki and I.Tamura: J. Jpn. Inst. Met., 50(1986), 602 (in Japanese).

21) K.Ameyama, G.C.Weatherly and K.T.Aust: Acta Metall. Mater., 40(1992), 1835.

22) T.Furuhara and T.Maki: Mater. Sci. Eng. A, 312(2001), 145.

23) Y.Adachi, K.Hakata and K.Tsuzaki: Mater. Sci. Eng. A, 412(2005), 252.

24) T.Takeuchi, Y.Adachi, D.Dorner and M.Enomoto: Mater. Sci. Forum, 561-565(2007), 69.

25) G.H.Zhang, T.Takeuchi, M.Enomoto and Y.Adachi: Metall. Mater. Trans. A, 42(2011), 1597.

26) T.Tomida, N.Imai, K.Miyata, S.Fukushima, M.Yoshida, M.Wakita, M.Etou, T.Sasaki,Y.Haraguchi and Y.Okada: ISIJ Int., 48(2008), 1148 .

27) T.Tomida, M.Wakita, M.Yasuyama, S.Sugaya, Y.Tomota and S.C.Vogel: Acta Mater., 61(2013), 2828.

28) I.Lischewski and G.Gottstein: Mater. Sci. Forum, 495-497(2005), 447.

29) I.Lischewski and G.Gottstein: Acta Mater., 59(2011), 1530.

30) K.Hata, M.Wakita, K.Fujiwara, K.Kawano, T.Tomida, M.Sugiyama, T.Fukuda and T.Kakeshita: Mater. Trans., 57(2016), 1514

31) K.Hata, K.Fujiwara, K.Kawano, M.Sugiyama, T.Fukuda and T.Kakeshita: ISIJ Int., 52(2018), 323.

32) H.I.Aaronson, T.Furuhara, J.M.Regisbee, W.T.Reynolds, Jr. and J.M.Howe: Metall. Trans. A, 21(1990), 2369

33) M.Enomoto: Acta Metall., 35(1987), 935.

34) M.Enomoto and H.I.Aaronson: Scr. Metall., 23(1989), 1983.

35) T.Fukino and S.Tsurekawa: Mater. Trans., 49(2008), 2770.

36) G.Miyamoto, R.Hori, B.Poorganji and T.Furuhara: Metall. Mater. Trans. A, 44(2013), 3436.

37) S.Zaefferer, S.I.Wright and D.Raabe: Metall. Mater. Trans. A, 39(2008), 374

38) M.Humbert, H.Moustahfid, F.Wagner and M.J.Philippe: Scr. Metall. Mater., 30(1994), 377.

39) M.Humbert and N.Gey: J. Appl. Crystallogr., 35(2002), 401.

40) C.Cayron, B.Artaud and L.Briottet: Mater. Charact., 57(2006), 386.

41) T.Morimoto, F.Yoshida, I.Chikushi, H.Kitahara and N.Tsuji: Tetsuto-Hagané, 93(2007), 591 (in Japanese).

42) G.Miyamoto, N.Iwata, N.Takayama and T.Furuhara: Acta Mater., 58(2010), 6393

43) K.Hata, M.Wakita, K.Fujiwara and K.Kawano: Nippon Steel \& Sumitomo Met. Tech. Rep., 114(2017), 26.

44) Z.-D.Li, G.Miyamoto, Z.-G.Yang and T.Furuhara: Scr. Mater., 60(2009), 485

45) A. Greninger and A. Troiano: Trans. AIME, 185(1949), 590. 